\title{
Gender, Performativity, and Agency in Virginia Woolf: A Butlerian Reading of Orlando
}

\author{
Bakhtiar Sadjadi $^{*}$, Serveh Hozhabri \\ ${ }^{1,2}$ University of Kurdistan, Iran \\ *Corresponding author: b.sajadi@uok.ac.ir
}

\begin{abstract}
The present paper attempts to closely study Virginia Woolf's Orlando in terms of Judith Butler's concepts of gender, performativity, and agency. Woolf examines women, their struggles and positions in literary history, and their needs for independence. Themes in her works consist of gender relations, class hierarchy, and the consequences of war. In most of her novels, she moves away from the use of plot and character and, instead, emphasizes the psychological aspects of her characters. In Orlando, the protagonist lives through centuries and Woolf allows her character to transform into a female halfway during the novel. The novel is directly engaged in the women's position and mentality through the lines, dialogues, and events. The principal question of the present study focuses on the perspectives through which gender is presented and the way it could be observed in relation to Butler's theory of gender as performance. The current survey is further concerned with the angles through which the novel reflects gender troubles and identity crisis of the women, conventionally defined as a minor category, according to Judith Butler's poststructuralist approach to the analysis of identity. Consequently, there is a confluence between the development of Woolf's female characters in the novel and Butler's critical notion concerning the subject's attempts to present performativity in the form of an active agent.
\end{abstract}

Keywords: Agency, Feminism, Gender, Performativity, Subjection

\section{Introduction}

Throughout history, women's issues and positions have always been questioned by them, and, in particular, by female writers who have examined and represented these struggles. Virginia Woolf was one of the prevalent names one faces under the heading of feminist novelists and she has been widely explored as a writer concerned with feminist issues. A forerunner of the Modernist movement, she 
represented women's struggle and their positions in literary history and their needs for independence in her novels.

Orlando starts in the sixteenth century with the young nobleman Orlando, who was fond of writing. To run off from a fake woman, he goes to Turkey as the English Ambassador, where he, after more than a few days of long sleep, wakes up and finds himself transformed into a woman. As a woman, Orlando lives with a gypsy group of people for a while. Woolf portrays Orlando as one of her most notable works since Woolf broke the traditional conventions of her time. Woolf's management of gender in most of her novels, mainly in Orlando, helps us look at gender in a dissimilar manner, which is in a close association with Butler's critical standpoint. Butler has an innovative way of observing the categories of sex and gender in Gender Trouble. She criticizes the traditionally established attitudes towards sex and gender as two separate kinds and argues that gender is a culturally constructed issue. Butler (1990) contends that the concept of sex should not be regarded as former to gender in that they are both created within the society and by cultural factors. She asserts that 'the feminist subject turns out to be discursively constituted by the very political system that is supposed to facilitate its emancipation' (p. 3).

The present paper first explores the major instances of the literature review of the research on the novel. Then, in the section concerning theoretical framework, it is attempted to address Butler's contribution to the critical concepts including gender, performativity and agency. At this point, the authors have given a full treatment of the significant concepts regarding the process of subjection. The next section seeks to read the subjective condition of the characters in Orlando while examining the highly charged notions of gender, performativity and agency in Virginia Woolf's novel. The concluding section of the study provides the findings based on Virginia Woolf's representation of the female characters' mental status in affiliation with their attempts in altering from a passive subject to an active agent.

\section{Literature Review}

The existing analysis seeks to present sketches of some primary reading materials conducive to formulating the research questions and conducting the study accordingly. Feminism has been frequently scrutinized from diverse aspects in contemporary times. Most of the works on Woolf have demonstrated literary, historical, social, and even cultural phases of her novels. The following, however, is a review of the recent and most significant works on the novel in terms of its versatile responses to the woman question and subjectivity. 
Maria de Dens Duarte (2014) asserts that according to Woolf, the issue of women's nature and their proper status is a challenging question, and that is merely the point Woolf has concentrated on. It makes her a prominent feminist figure despite the fact that she rejected the label. Duarte demonstrates through which angle such controversies in the category of women have been influenced by Angela Carter's 'Opera Libretto' (p. 21). She mentions that Woolf's Orlando is the subject for many to write about, and precisely Woolf displays her interest in the issue of 'boundaries of gender' (p. 22) in her novel. Duarte suggests that how:

'Having looked at all the different aspects that make out the character of Orlando, as well as the narrator, it is responsible to conclude that Orlando indeed is aimed at a feminist audience, and also that the implied reader in the text is a feminist. Moreover, the possibility of this implied feminist reader being a female one has been explored, and it has been noted that Orlando was modeled after and written to Vita Sackville-West who of course was a woman.' (p. 23)

Chin-Yuan Hu (2013) scrutinizes Orlando and the importance of time in the novel from the viewpoints of Deleuze and Guattari. Throughout the article, the researcher, at the same time, applies the theory of normadology for developing the English tradition and culture. It is argued that Orlando becomes a woman to shift to a new fashion. The article contends that Woolf sought to change those traditions via her novel as she focused on a male/female binary opposition argues that 'Orlando/Orlando is a prototype of nomadic travel, and eventually a metaphor of travel' (p. 110).

Marte Rongstad (2012) explores the portrayal of gender in both Orlando by Woolf and Middlesex by Eugenides through the viewpoints of Judith Butler. She tends to find out from which perspective these two works break the categories of gender, and through which standpoint they develop a new-fangled attitude toward the concept of gender. Rongstad seeks to examine by which vantage point these two novels criticize the traditional conventions of the category of gender. Moreover, she utilizes Butler's notion of 'gender as performance' for illustrating her ideas. On Orlando, she writes:

'The clearest example of gender performance in the novel is found in Woolf's play with clothing and costumes ... The use of clothing to construct gender is again an example of cultural and social implications of gender, and it underlines Woolf's view that gender is not something absolute.' (p. 54) 
Rongstad further argues that Woolf depicts Orlando as the one whose personality remains stable and inexpugnable while her/his gender undergoes a tremendous refashioning. She asserts that Woolf demonstrates a modern attitude on an individual as profoundly complex and fragmented one. She states that Woolf criticizes the need to determine individuals after fraught identity categories. She indicates that Woolf denies the existence of male and female gender core through switching from the category of male to the phase of femininity without any alteration in Orlando's personality. Rongstad arrives at this conclusion that by applying the Butlerian idea of performativity on Orlando, it becomes thoroughly obvious that this notion is crystal-clear in Orlando's clothes changing. She writes that 'in Orlando performativity in the literal sense of the word is present through Woolf's frequent play with clothing and cross-dressing' (p. 87).

In a paper entitled 'Re-Constructing her/History: Forms and Functions of Problematising Time in Virginia Woolf's Orlando in the Context of Modernism,' Claudia Beispiel (2008-9) asserts that one of Woolf's primary concerns in Orlando is the notion of time, which plays a 'disarming device' in confronting 'the question of identity and representation of biography and history' (p. 3). She utters that:

'In a world where a shredding and slicing of clock time is challenged by the artist's foregrounding of an extreme subjectification of time, memory, and narration seal a pact in freeing the individual from the domination of temps while further offering coherence to experience and identity.' (p. 2)

Moreover, Maureen Gallagher (2008), in her study, mentions that Woolf, in two of her most significant works, Orlando and A Room of One's Own, admired Shakespeare. Gallagher articulates that it is necessary to consider 'Woolf's identification of Shakespeare as a gender natural or feminist-friendly writer must be qualified.' She notes that:

'Woolf draws on Shakespeare in general throughout Orlando to explore issues of gender identity, romantic love, and sex. While she taps into themes, such as anti-Petrarchism, hat arises throughout Shakespeare's corpus, the androgynous heroines from Shakespeare's romantic comedies such as Twelfth Night, As You Like It, and Merchant of Venice particularly inspire Woolf's creation of gender-crossing in Orlando.' (pp. 16-17)

In a similar treatment, Jane De Gay (2007) brings out Woolf's mastery in leading her readers to go through the history of a female tradition, where they can discover how history has influenced their way of writing (p. 62). Gay adds that Woolf 
believed 'there was no female Shakespeare' during the Renaissance as it was unattainable for a woman to 'write for the theatre.' Gay elaborates Woolf's achievement in Orlando as:

'Within her fantastic narrative and through her protagonist, a writer
who lives for 350 years and changes sexes part-way through,
Woolf traces the changing conditions for writers and reflects upon
the effects on gender on their experiences. Furthermore, by
incorporating parodies of literary and social history and biography
into Orlando Woolf also critiques scholarly apparatus for viewing
the past, thus developing her ideas about the writing and rewriting
history.' (p. 63)

Esther Gonzalez (2004) in an essay entitled 'What Phantasmagoria the Mind Is: Reading Virginia Woolf's Parody of Gender,' endeavors to demonstrate in what manner Woolf's Orlando functions as an opposition to the norms and conventions of the late Victorian era regarding its 'sexual codes' which ruled upon each individual. Gonzalez states that 'the contradictory manly and womanly appearances of Orlando are resolved with the creation of an androgynous being whose gender is constantly mocked' (p. 75). She assumes that the main concern in Woolf, as a Bloomsbury intellectual, is same-sex love, which is manifested in Orlando. Gonzalez further appends that the novel arrives at the conclusion in which the appearances can never determine what one is:

'Woolf's Orlando is much more complex than an essence one can move or mask. What I mean by this is that neither the body of a man, nor the body of the woman, can represent adequately what a woman is, since women have been written out of discourse. What Woolf does in order to present the unrepresentable is play with performance.' (p. 84)

Pamela L. Caughie (1989) and Lydia Blanchard (1985) have addressed the affiliation between Woolf's novel and feminism in different ways. Caughie posits that Orlando can be argued as a feminist text since its author is a female one, and it has been argued that it was written for Woolf's friend who was a female. According to Caughie, "Orlando works as a feminist text not because its protagonist is androgynous but because of its discourse duplications" (p. 41). In contradiction, Blanchard (1985) addresses the issues between Woolf's writings and the responses her critics have had on her works. She believes that "Woolf is a major author, and she is a political writer, one whose aesthetic decisions are also 
political and thus one whose fiction and criticism must be understood, in relation to each other" (p. 95).

\section{Theoretical Framework: Critical Concepts}

\section{Gender}

In Gender Trouble (1990), Butler addresses the issues regarding the idea of gender and its affinity with sex and sexuality. According to her, gender is not something we acquire by birth; on the contrary, one constitutes its gender by acting. What we do is central, rather than what we have, thus without doing, we have no gender. Acts are therefore significant in making one's gender as Butler proclaims:

'Because there is neither an 'essence' that gender expresses or externalize nor an objective ideal to which gender aspires, and because gender is not a fact, the various acts of gender create the idea of gender, and without those acts there would be no gender at all.' (p. 190)

Gender does not bear an innate feature, nor is it manifested in the form of the essence; it is only through acting, or doing things repeatedly, that one is successfully capable of establishing his/her gender. Butler argues that "gender is an identity tenuously constituted in time, instituted in an exterior space through a stylized repetition of acts" (p. 191). Based on this definition by Butler, Gill Jagger (2008) asserts that "gender is a matter of the repetition of gender acts" (p. 28). He notes that one's identity consists of such acts as well as the "sense of a psychological interiority," which are "fictional products of reproductive heterosexuality" (p. 8). However, the notion of heterosexuality itself includes significant regimes in which Jagger argues Butler's claim that "identity categories are fictional products of these regimes of power, power/knowledge or power/discourse rather than natural effects of the body" (p. 17).

Elena Loizidou (2007) further elaborates this point and delineates that 'Butler shows how gender is a process, not an essence that exists before subject formation' (pp. 1-2). Our sex thus exists before the formation of our subject, whereas our gender does not. Loizidou argues that norms for Butler are a type of social power, which creates 'intelligible fields of subjects.' Moreover, that power serves as a means via which gender binary is instituted; therefore, gender is the creation of norms and power. Loizidou argues that Butler brings 'disciplinary power and gender' to propose that 'how genders' could be 'understood as intelligible and how 
others are foreclosed from the spectrum of intelligibility' as 'intelligible gender' according to Butler is the one which maintains a 'stable and continuity between sex, gender, sexuality, and desire' (p. 124).

In Gender Trouble (1990), Butler is engaged in the performativity of gender and emphasizes that gender is always a "doing," by that deed, a subject is formed; however, that subject is not prior to the gender itself. She declares that "gender proves to be performance, which constitutes the identity it is purported to be." In this sense, "gender is always a doing though not a doing by a subject who might be said to pre-exist the deed" (p. 34). She enunciates that "gender is not a noun, but neither is it a set of free-floating attributes, for we see that the substantive effect of gender is performatively produced and compelled by the regulatory practices of gender coherence" (p. 34).

\section{Performativity}

The issue Butler highlights as performative is considerably recognizable from the performance. Performative is not an alternative to be selected, whether by intention or not; rather, it is an action one constantly does. Butler's performative notion includes "acts, gestures," and it is the 'repetitious citations of sex and gender' (Craver \& Chambers 2008, p. 43). In Gender Trouble, Butler (1990) believes that defining the meaning of the notion of 'performativity' is difficult for the reason that it 'might vary over time' (p. xv). By posing the notion of performative, Jagger argues, Butler tends to go further and consider 'the subject' not only positioned in its 'formation in history and culture' but also asserts that it is 'socially and culturally constituted' (pp. 36-7). Jagger states that performativity is based on the 'speech act theory'; however, the subject's identity constitutes in 'regimes of power and knowledge characterized as compulsory heterosexuality and phallogocentrism. As a result, 'it is the matter of social and political regulation' ( $\mathrm{p}$. 20).

Butler reconsiders Althusser's conception of interpellation by being addressed the subject becomes socially established. The policeman stands for law and by making the call, he affects the subject. Thus, the one, who is called, is not totally a subject who is sociable, in that he/she 'is not yet reprimanded' (p. 79). The act of calling is vital for the formation of the subject, who is social, thus according to him, 'the call is formative, if not performative' since it 'initiates the individual into the subjected status of the subject.' 
Kirby (2006) notes that Butler turns to Derrida's deconstruction of Austin since she finds out the explanation of such repetition in 'language' (p. 95). Derrida's analysis in 'Signature Event Context' proves that 'any purported entity, whether a sign, a speech act, an individual intention or specific context, will be hailed by the force of repetition and re-contextualization' (p. 96), which is a 'force' that breaks 'identity from inside' (p. 95). According to Butler (1988), 'Derrida's performativity opposes the structural dimension of language to the semantic and describes an autonomous operation of the structural apparently of social residue' (Kirby 2006, pp. 105-6).

For Butler, 'performative speech acts are dynamic dialectic between the past, and present, the one that names and the one that is being named' (p. 42). Butler also asserts that performativity is not external to discourse. In addition, iterability is thus a set of norms and through which the subject gets the ability to be constructed. However, Butler does not mean any singular action; therefore, whatever is done even by 'norms of sex' is performative; that is why gender is more essential than sex for her. Whilst Butler argues sex is a 'gendered category,' she means performativity in the action of a gendered subject; that is why she ignores what feminism draws as a distinction between sex and gender, when she writes 'the category of sex always reinscribed as gender' (p. 4).

Butler's concept of performative is in close association with her perception of gender. Loizidou (2007) asserts that Butler's speculation in gender is one that suggests an 'understanding' the notion of the 'subject and politics' that rises from 'what is repudiated, forgotten, or put aside' (p. 39). Therefore, the indication of 'gender performativity' starts a 'reinterpretation of political moments of subject of enlightenment set aside, and considered unintelligible' (p. 39). Performativity brings the subject into existence, and it is the performativity of gender that makes a coherent interrelationship between identity categories.

\section{Agency}

In Gender Trouble, Judith Butler argues that the analysis of agency finds itself in a kind of theory which is driven from performativity in all that there should be an act which is performed by an agent, and that act is performative. There is a direct link between the subject and the process of repetition, as well. The subject is established through those repetitions; however, it is not governed by the tenant that is made. On the contrary, by the act of repetition, and since the subject is working through repetition, the same process is observed in the function of the agent. 
As Butler (1990) insists, the agency is not external to discourse, since the subject itself is not outside of the process; the subject would always remain inside discourse The process of construction in Butler's oeuvre is not opposed to agency She asserts that 'there is no possibility or agency or reality outside of the discursive practices' (p. 202). Moreover, there is a connection between the identity as a practice, and that of a linguistic life where the language is the only tool that involves signs which make intelligibility Agency is not the possibility of an 'I' which is prior to signification, instead this ' $\mathrm{I}$ ' is constructed via the process of signification.

Language thus plays a vital role in subject formation and the construction of identity. Language is not external to the process, and that ' $\mathrm{I}$ ' functions within the language. The question of the ' $\mathrm{I}$ ' is permanently inside the process, and for the agency, the matter of repetition is always at hand. Language is extensively significant in Butler's view since it provides the possibility of repetition and the constitution of the subject.

Butler has borrowed the concepts of supplementarity and restorability from Derrida. If there exists a 'subject' who performs his/her gender, this is due to the fact that 'language generates identities endlessly owing to its law of supplementarity' (p. 187). For Butler, it is the notion of 'reiteration' which allows one's identity to exist within discourse (p. 188). On the other hand, Thiem argues that Butler's perception of agency and its capability lies in 'Foucault's psychoanalysis and Derrida's notion of citationality' (p. 78). One could contend that agency is a variety of ability, which works within norms.

In Excitable Speech (1997), Butler writes that the very first conception that a subject might be established through is language, and this impression of language is what Althusser used for his theory of interpellation. She notes that when one calls someone, this might be the first assault to that person, as she writes 'to be called a name is one of the first forms of linguistic injury that one learns' (p. 2). Butler asserts that when one is addressed, s/he comes out of the context, and when $\mathrm{s} / \mathrm{he}$ answers and replies, it means that the one who is called response without any boss, force or authority supervising him/her.

In Bodies that Matter (1993), Butler postulates that agency comes from an 'I,' which is derived from a subject, and is in close relation to power, while tends to oppose it. Thus, when the 'I' does the opposite of what the power expects, the agency would be established (p.83). Consequently, the agency comes out of a chain signifier, and it is not only constructed by that chain, but it is also cited there; 
it creates an identity that is guaranteed by the notion of repetition and identity here tends to foreclose.

In The Psychic Life of Power: Theories in Subjection (1997), Butler distinguishes the process of subjection as a form of 'power' and asserts that this concept is governed by the outside of 'oneself,' for figuring out 'what one is' (p. 1), the one relied upon power for its form. She professes that Foucault's notion of power forms the subject, as well as making the settings available in which subjects would be created. This is what one relies on for its being; hence, for understanding this process, Butler writes that the process of subjection might have happened through one of the following ways: whether by Althusser's 'interpellation,' or Foucault's 'discursive productivity' (p. 2). Although Butler finds out that there exists a problem within Foucault's theory and there she expresses: 'he does not explore the specific mechanism of how the subject is formed in submission' (p. 2). She adds that 'the entire domain of psyche remains largely unmarked in his theory' (p. 2).

In Butler's view, the subject is subjected through language and gains intelligibility. Donald E. Hall (2004) proclaims that Butler is mostly interested in the 'possibility of individual agency in achieving that de-institutionalization' (p. 105). Hall argues that the question of placing agency within the culture is highly remarkable for Butler. As the subject is constructed culturally, discourse and culture are not of assistance for it to be constructed; instead, they drown the subject in themselves.

\section{Investigating Virginia Woolf's Orlando: A Butlerian Reading}

\section{Construction and Representation of Gender}

The present section aims to attentively analyze Virginia Woolf's Orlando based on Judith Butler's concepts of gender construction and identity. Woolf attempted to reflect the issues of gender and identity in her novel and manifest gender as an act of performance rather than an internal pre subject entity. The focus of this section would be on the representation of gender in the Victorian era and the manifestation of gender construction in major female characters through the repetition of various deeds.

The first points to be considered in the construction of gender are the dress codes and feminine style of clothing. Gender in the Butlerian perspective could not be regarded as a radical choice of the individual, nor is it imposed or inscribed upon them. Gender is the outcome of the repetition of several unconscious deeds. In this respect, Woolf has illustrated a collection of so-called Victorian women who 
drastically oppose each other in appearance. However, they are all accepted as Victorian female figures, since they insensibly repeat the socially expected acts such as being engaged with a male figure or having a heterosexual affair.

On the surface, Sasha stands out while Orlando describes the four ladies as Clorinda, 'a sweet-mannered gentle lady' (p. 18), Favilla, 'the daughter of a poor Somersetshire gentleman,' and Euphrosyne, who 'was by birth one of the Irish Desmonds' (p. 19). He describes Sasha as a 'clouded' and mysterious woman who 'was like a fox, or an olive tree; like the waves of the sea when you look down upon them from a height; like an emerald; like the sun on a green hill which is yet clouded' (p. 27). Being a courageous woman, she was considerably distinguishable from the other ladies around her.

Regarding the social nature of human beings, the deeds are witnessed, reproduced, internalized, and thus possess a performative or theatric value. Consequently, the proper actions for men and women have been transmitted to create a social ambiance that both controls and legitimizes a natural gender binary. By representing Sasha, Woolf insists on the issue that gender does not exist as an innate quality; yet, it is a matter of performance. Sasha takes the position of an unladylike female figure due to her deeds; for instance, she danced on the ice in pants, not worn by women at that time, or she barked like animals. 'Her courage made nothing of the adventure. She would come alone, in her cloak, and trousers, booted like a man, light as her footfall was, it would hardly be heard, even in this silence' (p. 35).

Sasha's persistence in being unfeminine and her insistence in remaining an iconoclast through performing deeds against the established norms demonstrate her eccentric character. Yet, she has been portrayed as a nonconformist female figure; in other words, she obtains her gender the same way as others by repeating the rituals and cultural deeds. Orlando loved her for what he could not see in other women and he might have adored her for what she possessed, not like a typical woman. Unlike Victorian women, it is Sasha who ends her relationship with Orlando and due to her heterodoxy, Orlando unfairly accuses her of other issues. When the time came and Orlando found out that she left him, he:

'Standing keep deep in water he hurled at the faithless woman all the insults that have ever been the lot of her sex. Faithless, mutable, fickle, he called her; devil, adulteress, deceiver; and the swirling waters took his words, and tossed at his feet a broken pot and a little straw.' (p. 38) 
After being heartbroken, Orlando takes refuge in the act of writing, which is genderless as both female and male writers inscribed masterpieces in the Victorian era. It could be mentioned that Orlando's gender purgatory occurred in that period, as he transforms into a woman after the time of his excessive writing.

Another character whose performance affects Orlando is Archduchess Harriet Griselda, who is a disguised male lover of Orlando. By presenting a homosexual love, Woolf once more displays that the performance of gender itself creates gender. The time Orlando transforms into a woman, he confesses that since he was in love with him, he has been under disguise as a woman to be close to him. Judith Butler compares the performativity of gender to the performance of the theater as the idea of each individual functioning as an actor of their gender could be traceable in the two characters mentioned above.

Although Orlando has been sexually altered into a woman, he still embodies some of the personality traits of his male identity; thus, the sexual transformation was not conspicuously influential in his identity. Gonzalez (2004) views Orlando's change as an ambiguous issue and writes:

'The narrator exploits the gender ambiguities of both characters by strategically blending her voice with Orlando's, and thus creating confusion for the reader who might think that Orlando is the woman indeed. Woolf needs to persuade the reader of the fact that Orlando has become a woman.' (p. 78)

Woolf's ingenious representation of gender reaches its peak in Orlando's sexual transformation to manifest gender as an unstable and fluid entity apart from one's sex organ. Orlando's character remains stable through the novel while she merely portrays herself as a woman by performing and repeating several deeds. Having left Turkey with an old gypsy, Rustum, Orlando learns how to act as a tribal woman, a fact that illustrates gender construction through performing and redoing established deeds.

Another issue that exhibits gender as a culturally and socially constructed sequel is being treated as a woman rather than being a woman. In other words, Woolf brings the construction of gender to shine light through that being treated as if a female has a tremendous effect on one's interpretation of one's gender as a female. While she was on her way back to England, she recognized how being a woman could influence men by being treated like a woman who possesses her in the status of a female character among them. Since she is a woman, the captain considers her worthy of more attention. 
She even contemplates seeking pleasure through the role the shipmen bestowed her as a woman. Comparing both genders, Orlando compares being a man with getting benefits from being a female and concludes that through playing the role of a woman and re-performing solid deeds, she would be able to obtain more advantages in life. Following the rules of being an irresistible woman, she commences acting as a seducing woman through the established belief of 'to resist and to yield' (p. 92).

A revolutionary impression of pondering on her gender as a culture-bound phenomenon is traceable in Orlando's redefinition of the female gender. Reforming the meaning of womanhood, Orlando's previous image of women as stupid and 'must be obedient, chaste, accented, and exquisitely appareled' (p. 93) alters into a new sort of experience for her.

'There is the hair-dressing,' she thought, 'that alone will take an hour of my morning, there's looking in the looking-glass, another hour; there's staying and lacing; there's washing and powdering; there's changing from silk to lace and from lace to paduasoy; and there's being chased year in year out...' (p. 93).

The concept of gender is seen as natural or innate since the body becomes its gender through a series of acts which are, revised, and consolidated through time; however, Orlando experiences the way gender is produced and reproduced via accepted acts and manifests his genderless identity by remaining the same person after his sex organ alters.

Woolf represents the fluidity of gender in several other issues; for instance, Orlando displays her devastation of not being able to perform her previous manly deeds. It obviously illustrates that she still has a keen interest in his masculine habits at the time she is sexually a female. 'Better is it, to be clothed with poverty and ignorance, which are the dark garments of the female sex; better to leave the rule and discipline of the world to others' (p. 96).

Moreover, the ironic scene in which the court regards Orlando as feminine and declares that her marriage is acceptable and she could own her properties, approves the point that gender could be socially redefined through a series of acts 'Sex? Ah! What about sex? My sex,' it 'is pronounced indisputably, and beyond the shadow of a doubt (what I was telling you a moment ago, Shell?) Female' (p. 151). Butler (1988) proclaims, 'Gender is what is put on, invariably, under constraint, daily and incessantly, with anxiety and pleasure’ (p. 531). 
Woolf endeavors to exhibit being a wife or a mother as a type of choice rather than a pre-subject entity. She demonstrates Orlando as a wife and a mother, yet with the same identity she had while she was a male character. Accordingly, Rongstad (2012) argues that: 'To avoid the limitations of her present time, Woolf created her own universe in which she was able to reveal the gendered body as a construction and to show that gender is not fixed, but rather fluid' (p. 51). In other words, Orlando's transformation is to a great extent about her performance and deeds rather than her sexual alteration.

It could be concluded that Woolf has manifested the fluidity of gender via various characters in the novel. Sasha, Harry, and Orlando experience an occurrence; however, their identity remains fixed. Woolf emphasizes the issue that gender does not have any affinity with sex and Orlando remains the same person after her physical transformation. Gender has been displayed as an acquirable entity through the repetition of multiple deeds.

\section{Manifestation of Performativity}

Performativity is highly distinctive from performance in the Butlerian perspective. One's gender is in close affinity with performativity in that only by performing one's gender his/her gender would be confirmed and constructed. In the present section, some instances from the text have been demonstrated to elaborate on the manifestation of performativity in the characters in Orlando. Elaborating on the issue that gender is performative, it should be mentioned that gender is 'real only to the extent that it is performed' (Butler 1990, p. 35). Therefore, the pre-existed identity considered as genderless gender identity is not coherent and stable. Sasha as an outstanding unladylike female figure in the novel manifests herself through repetition of a series of acts. She wears pants that stand for her nonconformity and appears in public with no fear of being rejected. Her definition of womanhood is largely various from the others' such as Clorinda, Favilla or Euphrosyne. By representing Sasha, Woolf emphasizes the fact that femininity and womanhood are of diverse definitions and multiple representations. It could be asserted that by performing several acts and repeating them, the purport of feminine gender undergoes alteration.

Gender, in the Butlerian viewpoint, could be comparable to a theatrical role in which repetition of the acts not only produce and reproduce the gender, but they also provide the atmosphere in which the gender codes could survive. As Butler (1990) states, 'repetition is what enables a subject, and constitutes the temporal condition for the subject' (p. 95). 
The apparent instance of the construction of gender via performance could be observed in Orlando while he transforms into a woman. Woolf portrays the female Orlando and the male one alike; therefore, Orlando's identity remains stable while she attempts to represent her femininity through the acts she performs. Whist she resides in a tribe, she represents herself as a tribal woman by repeating some deeds. She 'milked the goats; she collected brushwood; she stole a hen's egg now and then' (p. 84). Juxtaposing her tribal manners with her urban bearing, it could be delineated that femininity has various definitions for her. Gonzales (2004) argues that:

'Woolf describes Orlando as she steals 'a hen's egg now and then' - although the author excuses her for she 'always put a coin or a pearl in place of it.' A very sophisticated action emerges hidden among the completion of the numerous masculine tasks such as herding cattle, treating the grapes, or drinking from the goat's skin.' (pp. 79-80)

Orlando's disapproval of several womanly deeds once more illustrates the fact that the established feminine and masculine deeds are socially constructed. 'First, they noticed that she was less adept than before at milking and cheese-making; next, she often hesitated before replying' (p. 87). Performativity of gender is traceable in Gypsy's women as well. They are called women and considered females of the tribe; however, they 'except in one or two important particulars, differ very little from the gypsy men' (p. 91).

The svelte and fluid connotation of female gender and its construction through performing accepted and expected deeds are represented in the novel. Moreover, Woolf rejects the idea that feminine gender could be regarded alike while she juxtaposes tribal women with Victorian female characters. While British women tried to spend their time doing makeup, gypsy women were involved in the same activities as their men. Rongstad (2012) argues that 'Woolf shows how gender conventions are based on social norms that sometimes can be hard to understand, but Orlando, who has inhabited both sides, plays her part as a woman to perfection' (p. 34). Moreover, she argues that 'Woolf's play with clothes and disguises presents a performance of gender in Judith Butler's sense of the word, as it reveals the very 'constructedness' and arbitrariness of gender category' (p. 39).

It could be concluded that Virginia Woolf has flaunted the notion of gender as fluid and obtainable via several repetitive acts. Considering the point that the actions and codes have been defined and established by society and culture, gender could be observed as a culturally constructed entity. The non-identity between sex and 
gender is apparent in Orlando, Sasha and Harry's cases. Orlando's identity remains stable after his sexual transformation while she endeavors to make herself socially accepted by repeating several acts. Sasha resists coping with the established image of women and femininity and Harry undergoes a disguise to gain his beloved's attention (p. 39).

\section{From Subjecthood to Agency}

This section aims to investigate through which angles the subjects attempt to resist the established norms and ideas of their era and manifest by which actions they succeed or are defeated in their resistance. Additionally, the performativity of gender as the trigger of producing agency would be elaborated. The focus of this section will be mainly on Orlando, Sasha, and Harry since they are the emblems of nonconformity and resistance.

Considering Sasha as the first character who resists the established Victorian norms for women, her repetitive countercultural deeds bring about the possibility of agency. Her persistence in appearing in men's clothing such as pants and barking like animals provides a delignification in the Victorian discourse of femininity. Judith Butler argues that gender and gender identities are constructed through ritualized repetition and she asserts that via this continuous process subjects are produced and regulated.

This repetition in its core provides the possibility of alteration and resistance that requires the reworking of gender norms. By mentioning the politics of parody and cross-dressing, Butler commences by explaining the resistance, and she develops her argument with reference to the speech act theory. She demonstrates discourses constituting subjectivity via citation and recitation and emphasizes the point that it provides the likelihood of transformation. Butler mentions that the process of repetition is without closure and it paves the ground for subversive repetition and hence agency.

Harry's case is born out of resistance as she cross-dressers to get the chance to be close to his same-sex beloved. His disguise as a woman and his serious, constant, and abiding crush on Orlando re-signifies the notion of love and passion. After his real gender is revealed, Harry, once more, stands out as a parody of the fictional heroes in the Victorian era. In both representations of female and male characters, Harry/Harriet serves as a ridiculous non-conformist figure whose dull outlook and slow wit represent the opposite of what was expected from a nobleman. 
Butlerian view of agency does not have an affinity with the metaphysical aspect of the self; it rather considers the concrete conditions under which agency could be produced. Butler (1995), in Feminist Contentions, states that 'agency is a contingent possibility that is the effect of historically specific discursive conditions and power relations' (p. 144). Butler underlines the issue that is constituted by discourse is various form and not necessarily be determined by discourse.

Orlando's first representation of resistance could be observed in not being involved in a typical heterosexual affair. He selects Sasha, a tomboy, as a partner and later falls head over heels in love with her. His taste in women stands opposite of the Victorian norms and his relationship re-signifies a regenerated male/female bond. As a woman after his transformation, Orlando varies from tribal women, which results in re-defining the concept of femininity among them. She even represents a diverse interpretation of nature and expresses her love of nature while the tribesmen abhor it and its ferocity:

'He showed her the fingers of his left hand, withered by the frost; he showed her his right foot, crushed where a rock had fallen. This, he said, was what her God did to men. When she said, 'But so beautiful,' using the English word, he shook his head; and when she repeated it, he was angry. He saw that she did not believe what he believed.' (p. 86)

Orlando gains the advantage of experiencing womanhood, and it paves the ground for her nonconformist signification of femininity. It could be concluded that Orlando's process of resistance and the state of the agency would be ongoing as she expresses dexterity in pretending to cope with the norms while believing in her credence. Sasha and Harry, as well, remain stable regardless of the negative consequences they bear.

\section{Conclusion}

The present study demonstrated that the notions of gender, performativity and agency are dramatically represented in Virginia Woolf's Orlando. The concept of gender and Woolf's revolutionary attitude toward femininity as a flexible and indeterminate entity exactly accord with the Butlerian perspective of gender. Sasha, Harry and Orlando gain and manifest their gender identity through performing some deeds. The performativity of gender, hence, has been exhibited through the process of repeated rituals and the non-identity between sex and gender has been emphasized. The fluidity of gender stresses the point that it is socially and 
culturally constructed and could be altered through time. The consequence of resistance against the established rules has been spotlighted through the Butlerian agency. The procedure of signification and delignification paves the ground for the possibility of change in the novel while the subjects are constituted in society yet not determined.

Whereas some studies refer to the indication of the feeble and solid points of both sexes in the novel, some other critics believed that Woolf endeavored to portray the history of England. She might strive to reveal the status of women and the magnitude of their gender and the way throughout history; women have been treated by the discourse, society and men. Also, she exposed people's status in society in each era. It is Woolf's technique to create such an ambiance for her readers to lay it bare that if the case is confusing, so is the issue of gender.

\section{References}

Allen, Judith. (2010) Virginia Woolf and the Politics of Language. Edinburgh: Edinburgh University Press.

Ashraf, Rabia. (2017) Psychodynamics of Mother Daughter Relationship: Degrees of Deprivation, Oppression and Dispossession in Doris Lessing's Fiction. In: Khazar Journal of Humanities and Social Sciences, Vol. 20/1. (pp. 77-91). Baku: Khazar University Press. Retrieved from: DOI: 10.5782/2223-2621.2017.20.1.77.

Beispiel, Claudia (2008-9) (Re-)Constructing her-/his History: Forms and Functions of Problematising Time in Virginia Woolf's Orlando. Thesis, University of

Duisburg Essen

Benhabib, Seyla., Butler, Judith., Cornell, Drucilla., \& Fraser, Nancy. (1995) Feminist

Contentions: Philosophical Exchange. New York: Routledge.

Blanchard, Lydia. (1985) Virginia Woolf and her Critics: on the Discriminations of

Feminisms. Studies in the Novel, Vol. 17, No. 1, pp. (95-103)

Burns, Christy L. (1994) Re-Dressing Feminist Identities: Tensions between Essential and Constructed Selves in Virginia Woolf's Orlando, Twentieth Century Literature. XL (3), 342-364.

Butler, Judith. (2004) Undoing Gender. New York: Routledge.

---. (1997) Excitable Speech: A Politics of the Performative. New York: Routledge.

---. (1997). Psychic Life of Power: Theories in Subjection. Stanford, California: Stanford University Press.

---. (1993) Bodies that Matter: On the Discursive Limits of "Sex". New York: Routledge.

---. (1990) Gender Troubles. New York: Routledge

---. (1988) Performative Acts and Gender Constitution: An Essay in Phenomenology and Feminist Theory. Theatre Journal, Vol. 40, No. 4, pp. (519-531). The John Hopkins University Press 
Caughie, Pamela. (1989) Virginia Woolf's Double Discourse. (Ed), Urbana, IL: University of Illinois Press, pp.( 41-53)

Craver, Terrell. \& Chambers, Samuel. (2008). Judith Butler's Precarious Politics. New York: Routledge.

De Gay, Jane. ( 2007) Virginia Woolf’s Feminist Historiography in Orlando. Critical Survey. XIX (1), 62-72.

Duarte, Maria de Deus. (2014) What a Wonderful Piece of Work is a Woman: Orlando and the Enigma of the sexes, An Anglo-American Studies. 3, 21-42. Retrieved from: http://ler.letras.up.pt/ [accessed 15 August 2018]

Gallagher, Maureen. (2008) Thinking Back Through our Fathers: Woolf Reading Shakespeare in Orlando and A Room of One's Own. Thesis, Georgia State University.

Gonzales, Sanchez-Pardo. (2004) What Phantasmagoria the Mind Is: Reading Virginia Woolf's Parody of Gender. Atlantis. XXVI (2), 75-86.

Hall, Donald. E. (2004) Subjectivity. New York: Routledge.

Hu, Chin-Yuan. (2013) Metaphor of Travel: Virginia Woolf's Orlando, Travel Poetics. II (4), 110-132.

Jagger, Jill. (2008) Judith Butler: Sexual Politics, Social Change, and the Power of Performative. London and New York: Routledge.

Kao, pei-Wen. (2012) Queer live in Woolf's Orlando, and Chu's Notes on a Desolate Man. Comparative Literature and Culture, 14 (1). Article 6CLCWEB.

Kirby, Vicki. (2006) Judith Butler: Live Theory. London and New York: Continuum.

Loizidou, Elena. (2007) Judith Butler: Ethics, Law, Politics. New York: RoutledgeCavendish.

Martinez, Ernesto Javier. (2010) On Butler, on Morrison, on Language, Signs. 35 (4), 821842.

Rongstad, Marte. (2012) The Representation of Gender in Virginia Woolf's Orlando and Jeffery Eugenides's Middlesex. Trykk: University of Oslo

Rosenberg, Carol Beth. (2000) Virginia Woolf's Postmodern History, MLN. CXV (5), 1112-1130.

Thiem, Anita. (2002) Narrative Performativity: Theorizing Imaginative Remembering in Judith Butler's Concept of Subject Formation. Tubingen: University of Tubingen. Unpublished Dissertation

Wolfreys, Julian. (2006) Modern British and Irish Criticism and Theory: A critical Guide. Edinburgh: Edinburgh University Press.

Woolf, Virginia. (1993) Orlando. Ed. Brenda Lyons. London: Penguin Books. 